\title{
NATIONAL MODELS OF CORPORATE SOCIAL RESPONSIBILITY: COMPARATIVE ANALYSIS
}

\section{A. Pustokhin}

State University of Management, Moscow, Russia

e-mail: dpustokhin@yandex.ru

\section{V. Pustokhina}

Plekhanov Russian University of Economics, Moscow, Russia

e-mail: pustohina.iv@rea.ru

Abstract. The article is devoted to one of the most discussed topics of our time-corporate social responsibility (hereinafter-CSR). Discussions about the functions of business, its role in the development of society have been going on for several decades and do not lose their relevance to this day. Moreover, the implementation of CSR involves going beyond the statutory standards of business conduct. Companies strive to establish relations with the society and invest in its development, to strengthen its reputation, to harmonize the so-called «habitat». However, socially responsible behavior involves diverting part of the financial resources to solve tasks that are not directly related to making a profit.

Striving for prosperity in the long term encourages companies to find a balance between the need to invest in the social sphere and possible economic results. Aware of the fact that CSR can be not just a "gesture of goodwill», but also a serious tool for competition, companies actively include its principles in corporate strategy. One can say with confidence that CSR today is a global phenomenon, a practice that is being introduced in countries with different levels of political and social development.

Within the framework of this paper, the concept of the national CSR model is revealed. The article provides a comparative analysis of the national models of CSR developed in Western countries. Their main similarities and differences are determined. Based on the results of the comparative analysis, the authors propose recommendations on the formation of the Russian CSR model for state structures, the private sector, the media, the society as a whole.

Key words: society, business, non-commercial organizations, corporate philanthropy, public-private partnership, criteria, socially responsible investment, CSD, recommendations.

Cite as: Pustokhin, D. A., Pustokhina, I. V. (2020) [National models of corporate social responsibility: comparative analysis]. Intellekt. Innovatsii. Investitsii [Intellect. Innovations. Investments]. Vol. 5, pp. 93-103. DOI: $10.25198 / 2077-7175-2020-5-93$

\section{НАЦИОНАЛЬНЫЕ МОДЕЛИ КОРПОРАТИВНОЙ СОЦИАЛЬНОЙ ОТВЕТСТВЕННОСТИ: СРАВНИТЕЛЬНЫЙ АНАЛИЗ}

\section{Д. А. Пустохин}

Государственный университет управления, Москва, Россия

e-mail: dpustokhin@yandex.ru

\section{И. В. Пустохина}

Российский экономический университет им. Г. В. Плеханова, Москва, Россия e-mail: pustohina.iv@rea.ru

Аннотация. Статья посвящена одной из самых обсуждаемых тем нашего времени - корпоративной сочиальной ответственности (далее - КСО). Дискуссии о функииях бизнеса, его роли в развитии общества ведутся уже несколько десятилетий и не теряют своей актуальности и по сей день. Более того, реализачия КСО предполагает выход за рамки установленных законом стандартов ведения бизнеса. Компании стремятся наладить отношения с обществом и инвестировать в его развитие, укреплять репутацию, гармонизировать так называемую «среду обитания». Однако сочиально ответственное отношение предполагает отвлечение части финансовых ресурсов для решения задач, которые не имеют прямого отношения к получению прибыли. 
Стремление к проиветанию в долгосрочной перспективе побуждает компании находить баланс между необходимостью инвестировать в социальную сферу и возможными экономическими результатами. Осознавая тот факт, что КСО может быть не просто «жестом доброй воли», но и серьезным инструментом конкуренции, компании активно включают ее принципы в корпоративную стратегию. Можно с уверенностью сказать, что КСО сегодня - это глобальное явление, практика, которая внедряется в странах с различным уровнем политического и сочиального развития.

В рамках данной статьи раскрывается конџепџия наџиональной модели КСО. В статье приводится сравнительный анализ начиональных моделей КСО, разработанных в западных странах. Определены их основные сходства и различия. На основании результатов сравнительного анализа авторы предлагают рекомендации по формированию российской модели КСО для государственных структур, частного сектора, СМИ, общества в цчелом.

Ключевые слова: общество, бизнес, некоммерческие организации, корпоративная благотворительность, государственно-частное партнерство, критерии, социально ответственнье инвестиции, корпоративная прозрачность, рекомендации.

Для цитирования: Pustokhin, D. A., Pustokhina, I. V. (2020) [National models of corporate social responsibility: comparative analysis]. Intellekt. Innovatsii. Investitsii [Intellect. Innovations. Investments]. Vol. 5, pp. 93-103. DOI: 10.25198/2077-7175-2020-5-93.

\section{Introduction}

Corporate social responsibility is a type of selfregulatory business plan with initiatives focusing on achieving economic, social and environmental benefits for all stakeholders involved (employees, consumers, investors and other groups).

The concept of corporate social responsibility has different interpretations and is perceived differently in different spheres of activity and parts of the world.

According to the international standard ISO $26000^{1}$, social responsibility is the responsibility of the company for the impact of its decisions and activities on society and the environment through transparent and ethical behavior that:

promotes sustainable development, including the health and well-being of society;

- takes into account the expectations of stakeholders;

- $\quad$ corresponds to the applicable legislation and is consistent with international standards of conduct;

- $\quad$ is integrated into the activities of the entire organization and is used in its relationships.

Thus, CSR includes 4 aspects (Table 1).

Table 1 . The aspects of corporate social responsibility

\begin{tabular}{|l|l|}
\hline \multicolumn{1}{|c|}{ Aspects } & \multicolumn{1}{c|}{ Comments } \\
\hline Economic & $\begin{array}{l}\text { It defines the basic market functions of the company, such as satisfying the needs of consumers and } \\
\text { making a profit. }\end{array}$ \\
\hline Legal & $\begin{array}{l}\text { It speaks about the need to conduct an honest, law-abiding business, as well as the compliance of its } \\
\text { activities with the expectations of the parties concerned, again following the letter of the law. }\end{array}$ \\
\hline Ethical & It is about the need to conduct business in accordance with the social concepts of morality. \\
\hline Philanthropic & $\begin{array}{l}\text { It initiates the actions of companies to support and develop the well-being of society through voluntary } \\
\text { participation in various social programs. }\end{array}$ \\
\hline
\end{tabular}

A company operating in accordance with CSR principles should strive to profit, be law-abiding and ethical, and must be a good corporate citizen.

The modern academic community distinguishes several models of CSR, differing in some or other parameters and corresponding to the conditions of those countries in which they are formed. We are talking about American, European (continental), British, Canadian, Scandinavian, Latin, Japanese, Chinese and Islamic CSR models.

In accordance with this approach, the national CSR model is a set of distinctive features and peculiarities of interaction between the state, business structures, non-commercial organizations (NGOs) and the social characteristic of a certain country or group of countries (region) [3].

Within the framework of this paper, it was decided to focus on the analysis of Western CSR models such as:

- American;

- European (continental);

- British;

- Canadian.

ISO 26000:2010 (en) Social responsibility. Available at https://www.iso.org/iso-26000-social-responsibility.html. 
It seems advisable to carry out a comparative analysis of the designated Western models, to reveal their main similarities and differences.

Conducting a comparative analysis of national models makes it necessary to determine the criteria (comparative characteristics), according to which it will be implemented.

The nature of relations between the state, business, NGOs and society, together with the peculiarities in the country (historical, socio-political, economic, legal, mental, traditional) have a direct impact on the formation of national CSR models in individual countries or groups of countries (regions) [10], [16].

The list of criteria for comparing national CSR models will be as follows:

- $\quad$ Type of the model

- $\quad$ Nature of the model

- Presence of the main framework documents developed by the state/states

- Main initiators of CSR

- Position of the state

- Role of the business

- Forms of CSR implementation

- $\quad$ Perception of CSR idea by society

So, having determined the criteria, we will characterize the existing national CSR models in accordance with them.

\section{American National Model of CSR}

Corporate social responsibility in the US has a long tradition. The American model of CSR began to take shape over 100 years ago (at the beginning of the 20th century) and continues to develop to this day in unison with civil society.

Describing this national model, we should say it has a high share of social spending. The ever-increasing costs of medical care, pensions, support for war veterans aggravate an already difficult situation with a budget deficit and a systematically growing external debt, and there is a need to redistribute the functions of the state and the corporate sector [13], [14]. However, the choice of the application of forces remains for business [6]. The state tries not to interfere directly in the affairs of the private sector. It stimulates socially responsible behavior through tax incentives and credits, but it does not strictly regulate it and allows companies to independently decide in what forms and to what extent they will implement CSR principles. In other words, the business itself is the initiator of CSR.

On December 16, 2016, the Government of the United States adopted the First National Action Plan for the USA (hereinafter referred to as the Plan) ${ }^{2}$. This Plan is intended to strengthen the role of the US Government in promoting responsible business conduct through effective coordination of activities and the development of a common policy to promote high standards of doing business all over the world, expand cooperation, and support the leading companies. This document focuses on the initiatives of the US Government related to US companies operating abroad. It focuses on five categories of initiatives:

- Set an example for others.

- Cooperate with stakeholders.

- Promote the development of responsible business conduct of companies.

- Identify socially responsible companies.

- Provide access to a complaints mechanism and seek effectiveremedies.

Each of the five categories contains a description of specific government initiatives, as well as information on responsible executors. Although the document informs about the initiatives in a rather general form, it nevertheless allows us to assess the plans of the US Government for the further development of responsible business behavior. As reported in the document itself, the Plan promotes an open dialogue through which the Government informs interested parties about its intentions, coordinates and evaluates its own actions.

As previously mentioned, representatives of American businesses have the opportunity to independently determine the points of application of forces in the implementation of CSR, as well as possible forms of this implementation. Most companies consider their own shareholders, staff and local communities as key stakeholders. As priority areas of investment, they consider such problem areas as health, education, services to the local population (assistance to disabled people, veterans of wars,etc.) [9].

The most popular form of CSR implementation by American companies for a long period of time remains corporate philanthropy. Traditional for the United States is the establishment of large private companies or its owners of blogging funds. Examples of large private charitable foundations include The Bill and Melinda Gates Foundation; The Kellogg Foundation; The Humanity United Foundation, founded by the founder of eBay, Pierre Omidyar; Fund "Walmart", etc. Donations of large companies help solve many social problems, including poverty, human trafficking, exploitation of child labor, problems of school education, and others. It is also important to note that American companies mostly perceive philanthropy not as a one-time expression of goodwill, but strive for mutually beneficial cooperation with recipients in the long term. A strategic one gradually replaces the traditional approach tophilanthropy.

Responsible Business Conduct: First National Action Plan for the United States of America / US Department of State, 2016. Available at https://2009-2017.state.gov/e/eb/eppd/csr/naprbc/265706.htm. 
Other popular forms of CSR implementation in companies are targeted programs of different focus, as well as goal-oriented marketing strategies (suggest that part of the funds from the sale of goods will go to socially significant goals). Within the companies themselves, Social Security Funds are created, which provide funds for disability pensions, sickness benefits, etc. Employees of companies are actively involved in volunteer activities. Business and social organizations create «social alliances» that allow them to cooperate to solve socially significant problems.

In an effort to increase transparency and attract public attention to their own CSR initiatives, US companies are actively developing non-financial reports. To date, the United States is the leader in the number of reporting companies.

It is important to note that the preparation of nonfinancial reporting in the US is not in itself mandatory. It is voluntary. However, the disclosure of non-financial reporting is recommended by authoritative organizations (in particular the SEC) and is required by many stock exchanges (58 exchanges, including the New York (NYSE), have confirmed their intention to follow the Sustainable Exchange Initiative (SSE) in order to promote the principles of sustainable development on their markets ${ }^{3}$ [5].

Describing the CSR model in the United States, it is necessary to say that many spheres of society are regulated by society itself. Activist movements are widespread. Often it is public initiatives (pressure from activists) that motivate companies to act in the social sphere.

So, the American national model of CSR can be characterized as open. It is characterized by:

- minimal government intervention in the private sector;

- initiation of CSR by the companies themselves;

- a wide range of forms of implementation of CSR, including through numerous funds of different focus;

active social position.

All these characteristics create the basis for the American model, which has been worthwhile for many years.

\section{European (Continental) National Model of CSR}

The European (continental) model can be called the antipode of the liberal American model. It began to form in the 70s of the XX century, but the independent direction of the work of the European Union CSR was only in the early 2000's. (after the European Council meeting in Lisbon). This model covers states located on the European continent, excluding Great Britain, Iceland, Ireland, and other island states.

The European Union (EU) is an authoritative integration association. It has experienced not a large but steady increase in key economic indicators. However, despite this, there are a number of serious problems that concern not only the financial but also the social aspects of the activity, such as refugee problem, high unemployment and dependency due to high social benefits, population aging, the problem of preserving cultural and national identity, manifestations of racial hostility, and others [4], [17]. All these problems prompt state structures to take active measures to resolve them.

Today, in the issues of stimulating CSR in European countries, an active role is played by active state participation. As a result, we can observe the effective functioning of various acts that promote the principles of sustainable development [15]. Such actors include NGOs, trade unions, business associations (in particular, CSR Europe), etc. They influence the views of the population and various levels of power, as a result of which CSR is integrated into the sphere of public policy ${ }^{4}$.

State stimulation of CSR in European countries is carried out at all levels - international, EU level, the level of member states - in practically all accessible ways.

Speaking about the international level, it should be noted that the basis for the directives and initiatives adopted in the field of CSR by European countries are the provisions and regulations of the United Nations, ILO, OECD, and other authoritative actors.

Based on this «foundation», the European Union is developing its own initiatives. The most developed from a legal point of view to date are the social and environmental spheres [11]. They are dedicated to hundreds of directives, regulations and various kinds of programs. For example, within the framework of the European Program for Employment and Social Innovation (EaSI) for 2011-2020. The European Commission proposes to finance projects aimed at accelerating the integration of migrants and their families into the labor market $^{5}$.

Bove A., Swartz S. Starting at the source: sustainability in supply chains / McKinsey\&Company, 2016. Available at http://www.mckinsey.com/business-functions/sustainability-and-resource-productivity/our-insights/starting-at-the-source-sustainability-in-supply-chains.

100 World's most sustainable corporations / Corporate Knights, 2017. Available at http://www.corporateknights.com/reports/2017global-100/2017-global-100-results-14846083/.

Regulation (EU) No 1296/2013 of the European Parliament and of the Council of 11 December 2013 on a European Union Programme for Employment and Social Innovation («EaSI») and amending Decision No 283/2010/EU establishing a European Progress Microfinance Facility for employment and social inclusion / Official Journal of the European Union, 2013. Available at http://eur-lex.europa.eu/LexUriServ/ LexUriServ.do?uri=OJ:L:2013:347:0238:0252:EN:PDF. 
The European CSR model is characterized by a high degree of elaboration of the legislative base at all levels, which undoubtedly has an impact on the practice of implementing CSR by business representatives.

The activities of European companies are strictly regulated in accordance with the current labor, environmental and tax legislation. They are characterized by a high level of intercorporate regulation. Consider, for example, the activities of one of the leaders of the European community in the field of CSR - the German chemical and pharmaceutical company Bayer. The company implements programs in the following areas: research, education, environmental protection, health care, culture, sports. In addition, Bayer sponsors the development of social projects.

So, the European (continental) model of CSR can be described as closed. It is characterized by:

- $\quad$ high level of state regulation in the sphere of business and CSR;

- a deep study of the legislative framework;

- implementation of CSR by companies with an emphasis on mechanisms of state regulation and internal corporate regulations;

a wide range of forms of implementation of CSR (often in collaboration with government agencies);

increased attention of companies to transparency due to a lack of public confidence in the private sector.

\section{British National Model of CSR}

The most modern experts agree that the British national model of CSR combines features of both the American and European (continental) model, that is, it has a mixed («hybrid») character. The beginning of its formation started during late years of the twentieth century, and development continues to this day.

The United Kingdom is one of the largest countries in Europe, occupying the tenth place in the world in terms of GDP (at purchasing power parity) ${ }^{6}$. The country is known for its well- developed system of social security, health care, and education. According to the OECD Better Life Index, most welfare indicators personal security, environmental quality, civic activity, social connections, health, work and wages, housing conditions - are relatively high (above average) in terms of compared with other countries represented in the rating.

As for the European (continental), the British model is characterized by the active support of business by the state. It develops the necessary regulatory documentation, actively supports socially-oriented projects, implements CSR in the public procurement system, stimulates public dialogue on CSR, publishes information reports on activities in this area.

On the other hand, British companies, with the support of the state, independently initiate activities in the field of CSR. This is typical of the American liberal model. It is interesting that in some British companies, in particular Cadbury confectionery company, the traditions of social protection exist for several hundred years - since the activities of the religious movement of the English Quakers. These traditions formed the basis of the company's modern approach to doing business. In 2008, Cadbury invested 45 million pounds in the development of cocoa farms in Ghana, India, Indonesia and the Caribbean. In 2015, the Cadbury Foundation donated about $£ 600,000$ to support various social programs across the UK and Ireland?

The spectrum of forms of implementation of CSR by British companies is very extensive. It includes forms characteristic of both the American and European (continental) models: from one- time charitable donations to large-scale social investment projects. Particular attention is paid by British companies to the development of local communities. Large-scale social projects are implemented under the auspices of the Business in the Community, which brings together more than 800 business representatives: from small enterprises to global corporations [8].

An active position is occupied by trade unions subordinated to a single organization - the Trades Union Congress (TUC), which protect workers' rights on a wide range of issues related to working conditions. In most companies, there is a representative of trade union organizations.

Striving for transparency and openness, British companies are actively engaged in the preparation of non-financial reporting. To date, they rank second in the world in the total number of reports produced, second only to the United States.

Thus, the British national model of CSR combines aspects of the open American and closed European (continental) models. The active support of CSR by state structures is complemented by the initiative of the companies themselves. We can note, the business community prefers to formulate the agenda independently or in a dialogue with the state.

\section{Canadian National CSR Model}

The Canadian national model of CSR, like the British one, has a hybrid character combining the features of American and European (continental) models. Its formation took place in the late years of the twentieth century, and development continues to this day in unison with Canadian society.

\footnotetext{
GDP Ranking, PPP Based / World Bank. Available at http://data.worldbank.org/data-catalog/GDP-PPP-based-table.
}

Cadbury Foundation. Available at https://www.cadbury.co.uk/cadbury-foundation. 
Canada is a country that regularly occupies high positions in terms of the welfare and prosperity of society. Canada is in the TOP-25 of the world's richest countries.

Speaking about the Canadian national model of CSR, it should be noted that it is characterized by high activity from government agencies. The Government of Canada developed a Sustainable Development Strategy for the period from 2016 to 2019 , which sets out 13 goals that are consistent with the 17 goals of the UN Agenda until 2030: effective actions to prevent climate change; reduction of carbon emissions; «Pure growth», that is, the development of an economy based on alternative sources of energy; infrastructure development; use of «clean energy» ${ }^{8}$; cleanliness of the oceans and coastal areas; maintenance of cleanliness of lakes and rivers; support of biodiversity of ecosystems; care for the environment (support for all types of populations); ensuring the high quality of drinking water; use of innovations in the agricultural sector; ensuring the interaction of Canadian citizens with nature; ensuring the safety and health of local communities?.

The Government has a stimulating effect on the state-business-NGO system.

State structures of Canada also pay special attention to CSR issues in the extractive sector of the economy. To date, there is a CSR Promotion Strategy in Extractive Industries, which demonstrates the Government's expectation that companies will promote Canadian values and work abroad in accordance with the highest level of ethical standards ${ }^{10}$. In addition, in accordance with the Law on Measures for Ensuring Transparency in the Extractive Sector, Canadian companies are required to report on an annual basis on specific payments made in favor of the Government of Canada and abroad ${ }^{11}$. It was the Canadian mining expert (James Cooney) who in 1997, at a meeting with representatives of the World Bank, used the term «social license» for the first time to describe the quality of relations between mining companies and a local co-worker.

However, with all the activities of the Canadian Government, the initiators of CSR are still representa- tives of the business. State structures, in turn, create the necessary conditions for the dissemination of the best socially responsible practices. They developed a Guide to the implementation of CSR in the activities of Canadian companies, which contains practical advice on how to develop a business case for implementing CSR initiatives, how to form and continue to apply a socially responsible strategy, and how to measure the results obtained and disseminate the best corporate practices in the business community ${ }^{12}$.

To discuss a wide range of issues related to CSR, specialized organizations have been established, among them: CBSR, CCECP, CBC, etc. These organizations promote the dissemination of the best socially responsible practices, ensure transparency and openness in resolving issues, supply the company with the necessary information.

The spectrum of forms of implementation of CSR by Canadian companies is very extensive. Projects of public-private partnership are being successfully implemented.

Charitable organizations are widely distributed. Their total number exceeds $86,000^{13}$. Canadian companies are deeply involved in the process of creating a public good. For example, Four Seasons Company supports organizations involved in the fight against cancer [7], [12].

Speaking about the Canadian national CSR mod$\mathrm{el}$, it is necessary to pay attention to the fact that the position of the Canadian society regarding CSR and sustainable development is taken into account by state structures when drafting the Federal Strategy ${ }^{14}$.

Thus, the Canadian national model of CSR has a «hybrid» character. It combines features of the American (CSR initiation by the companies themselves) and European (continental) (increased attention from the state) models. This model seems to be the most effective and balanced. It is designed in such a way that it excludes pressure from the state, but at the same time, it allows identifying and effectively solving urgent social problems in the form of a multilateral dialogue in

The National Renewable Energy Action Plans / European Comission. Available at http://ec.europa.eu/energy/en/topics/renewable-energy/national-action-plans.

A Federal Sustainable Development Strategy for Canada 2016-2019 / Government of Canada. Available at https://www.canada.ca/en/ services/environment/conservation/sustainability/federal-sustainable-development-strategy.html.

10 Doing Business the Canadian Way: A Strategy to Advance Corporate Social Responsibility in Canada's Extractive Sector Abroad / Government of Canada. Available at http://www.international.gc.ca/trade-agreements-accords-commerciaux/topics-domaines/other-autre/csrstrat-rse.aspx?lang=eng. 1.html.

Extractive Sector Transparency Measures Act / Government of Canada. Available at http://laws-lois.justice.gc.ca/eng/acts/E-22.7/page-

12 Corporate social responsibility (CSR). An implementation guide for Canadian business / Industry Canada, 2014. Available at https:// www.ic.gc.ca/eic/site/csrrse.nsf/vwapj/CSRImplementationGuide.pdf/\$file/CSRImplementationGuide.pdf.

13 Brown M. Canada's top-rated charities / MoneySence, 2016. Available at http://www.moneysense.ca/save/financial-planning/canadastop-rated-charities-2017/Brown M. Canada’s top-rated charities / MoneySence, 2016. http://www.moneysense.ca/save/financial-planning/ canadas-top-rated-charities-2017/.

14 Sustainability and Reporting Trends in 2025.Preparing for the Future / Global Reporting Initiative (GRI), 2015. Available at https:// www.globalreporting.org/resourcelibrary/Sustainability-and-Reporting-Trends-in-2025-1.pdf. 
the «state-business-NGO-society» system. This model can be applied cliché «made by people for people». Particularly valuable is the fact that state structures take into account the opinion of the inhabitants of the country, thereby increasing the level of loyalty of society, forming a spirit of ownership.
Four CSR models were analyzed. Each of them has its own peculiarities, which make it possible to distinguish one national model from another. On the basis of the data discussed, a brief review can be made, allowing to form a general idea of the studied CSR models (Table 2).

Table 2. A brief review of CSR models

\begin{tabular}{|c|c|c|c|c|}
\hline Criteria & $\begin{array}{l}\text { American national } \\
\text { model of CSR }\end{array}$ & $\begin{array}{l}\text { European national } \\
\text { model of CSR }\end{array}$ & $\begin{array}{c}\text { British national model } \\
\text { of CSR }\end{array}$ & $\begin{array}{c}\text { Canadian national model } \\
\text { of CSR }\end{array}$ \\
\hline 1. Type of the model & Original & Original & Hybrid & Hybrid \\
\hline $\begin{array}{l}\text { 2. The nature of the } \\
\text { model }\end{array}$ & Open & Close & $\begin{array}{l}\text { Mixed (inclined to- } \\
\text { wards the closed) }\end{array}$ & Mixed (balanced) \\
\hline $\begin{array}{l}\text { 3. Presence of the } \\
\text { main framework } \\
\text { documents devel- } \\
\text { oped by the state/ } \\
\text { states }\end{array}$ & $\begin{array}{l}\text { Responsible Business } \\
\text { Conduct. First Nation } \\
\text { Action Plan for the } \\
\text { USA }\end{array}$ & \multicolumn{2}{|c|}{$\begin{array}{l}16 \text { of the } 28 \text { EU member states (including the } \\
\text { UK) have National CSR Action Plans }\end{array}$} & $\begin{array}{l}\text { 1. The strategy of sustainable } \\
\text { development for the period } \\
\text { from } 2016 \text { to } 2019 \text {. } \\
\text { 2. An Implementation Guide } \\
\text { for Canadian Business }\end{array}$ \\
\hline $\begin{array}{l}\text { 4. The main } \\
\text { initiators of CSR }\end{array}$ & Business & State & $\begin{array}{l}\text { Business with active } \\
\text { support of the state }\end{array}$ & $\begin{array}{l}\text { Business and the state as } \\
\text { partners }\end{array}$ \\
\hline $\begin{array}{l}\text { 5. Position of the } \\
\text { state }\end{array}$ & $\begin{array}{l}\text { Minimal interference } \\
\text { of the state in business } \\
\text { affairs }\end{array}$ & $\begin{array}{l}\text { High level of state } \\
\text { regulation }\end{array}$ & $\begin{array}{l}\text { Active support of the } \\
\text { state with the initiative } \\
\text { of the companies them- } \\
\text { selves }\end{array}$ & $\begin{array}{l}\text { The state initiates events that } \\
\text { unite the efforts of himself, } \\
\text { business, society and NGOs }\end{array}$ \\
\hline $\begin{array}{l}\text { 6. Position of the } \\
\text { business }\end{array}$ & $\begin{array}{l}\text { Activity of the compa- } \\
\text { nies themselves. State } \\
\text { intervention is per- } \\
\text { ceived extremely nega- } \\
\text { tively }\end{array}$ & $\begin{array}{l}\text { Implementation of } \\
\text { CSR by companies } \\
\text { with an emphasis on } \\
\text { government regula- } \\
\text { tion } \\
\text { mechanisms }\end{array}$ & $\begin{array}{l}\text { Business prefers to in- } \\
\text { dependently form an } \\
\text { agenda in the field of } \\
\text { CSR }\end{array}$ & $\begin{array}{l}\text { The business relies on state } \\
\text { initiatives, but at the same } \\
\text { time it is active }\end{array}$ \\
\hline \multirow{2}{*}{$\begin{array}{l}\text { 7. Forms of CSR } \\
\text { implementation }\end{array}$} & \multicolumn{4}{|c|}{ A wide range of forms of CSR implementation } \\
\hline & $\begin{array}{l}\text { 1. CSR is initiated by } \\
\text { the companies them- } \\
\text { selves, goes beyond the } \\
\text { statutory minimum. } \\
\text { 2. Implementation of } \\
\text { CSR principles to the } \\
\text { extent that modern } \\
\text { business rules require } \\
\text { and you can increase } \\
\text { the value of the com- } \\
\text { pany. } \\
\text { 3. Objects of entrepre- } \\
\text { neurship are maximally } \\
\text { freed. } \\
\text { 4. American TNCs are } \\
\text { «leaders» in the imple- } \\
\text { mentation of CSR prac- } \\
\text { tices. }\end{array}$ & $\begin{array}{l}\text { 1. The business } \\
\text { activity is strictly } \\
\text { regulated within the } \\
\text { framework of the } \\
\text { current legislation } \\
\text { (labor, environmen- } \\
\text { tal, tax). } \\
\text { 2. The JCB is carried } \\
\text { out within the frame- } \\
\text { work of internal cor- } \\
\text { porate regulations }\end{array}$ & $\begin{array}{l}\text { 1. It is based on the } \\
\text { traditions of social } \\
\text { protection, rooted in } \\
\text { the teachings of the re- } \\
\text { ligious movement of } \\
\text { English Quakers (this } \\
\text { is typical, for example, } \\
\text { for the confectionery } \\
\text { company Cadbury). } \\
\text { 2. Orientation to hon- } \\
\text { esty, reliability and so- } \\
\text { cial responsibility in the } \\
\text { conduct of business. } \\
\text { 3. Active business sup- } \\
\text { port of local communi- } \\
\text { ties. } \\
4 \text {. Involvement in CSR } \\
\text { of representatives of } \\
\text { small and medium- } \\
\text { sized businesses. }\end{array}$ & $\begin{array}{l}\text { 1. Active position of the } \\
\text { business community. Repre- } \\
\text { sentatives of business create } \\
\text { specialized organizations fo- } \\
\text { cusing on CSR and sustain- } \\
\text { able development issues (in } \\
\text { particular, Canadian Busi- } \\
\text { ness for Social Responsibil- } \\
\text { ity, CBSR). } \\
\text { 2. Close cooperation be- } \\
\text { tween business and the state. } \\
\text { 3. The initiators of CSR are } \\
\text { the companies themselves }\end{array}$ \\
\hline $\begin{array}{l}\text { 8. Perception of } \\
\text { CSR idea by society }\end{array}$ & $\begin{array}{l}\text { Support, activity, initia- } \\
\text { tive }\end{array}$ & $\begin{array}{l}\text { Distrust of the pri- } \\
\text { vate sector. CSR as } \\
\text { a legally stipulated } \\
\text { necessity }\end{array}$ & $\begin{array}{l}\text { From neutrality to ap- } \\
\text { proval. CSR as a desir- } \\
\text { able benefit }\end{array}$ & $\begin{array}{l}\text { Support. Readiness for dia- } \\
\text { logue with state structures } \\
\text { and business in CSR }\end{array}$ \\
\hline
\end{tabular}




\section{Recommendations on the Formation of the Russian Model of CSR}

At the stage of the initial formation of the national model of CSR, it is extremely important to take into account the rich experience that has developed in foreign countries. On the basis of a comparative analysis of the national models of CSR developed in Western countries, we will propose recommendations on the formation of the Russian CSR model for state structures, the private sector, and other actors.

\section{Recommendations for state structures:}

1. Develop a National Policy in the field of CSR

The need to create a unified Politics has «matured» for a long time. CSR standards have been consolidated in documents at the level of individual subjects of the Russian Federation. However, all these documents focus on different indicators, developed using different methods. Unfortunately, we can not talk about coherence in CSR regulation issues. The need for a framework state document is felt more and more.

2. Support public-private partnership (PPP)

The PPP mechanism is an instrument for developing regional and municipal infrastructure, attracting investments, improving the quality of services provided to the population.

The most favorable regions for the level of PPP development in 2019 are: Samara Region, Moscow, Moscow Region, Nizhny Novgorod Region, Perm Territory ${ }^{15}$.

3. Support and develop incentive actions for socially responsible companies

The construction of a system of material incentives is undoubtedly a very difficult task. The main difficulties are to find the necessary sums of money, as well as to distribute these amounts among the participants. Leading positions in the ratings are traditionally occupied by large companies, while representatives of medium and small businesses remain out of work. The solution of this problem (subject to the high interest of business representatives and the readiness to develop in the direction of CSR) may be the development of separate ratings for small, medium and large businesses.

The issue of developing a system of material incentives for socially responsible companies requires attention and careful consideration both from government agencies and from business organizations.

4. Improve tax legislation, develop a favorable business climate

The tax sphere has always been and remains a field for discussion. For example, in Russia the tax maneuver to reduce the rate of insurance premiums from $30 \%$ to $22 \%$ with a simultaneous increase in VAT from $18 \%$ to $22 \%$ was supported by some experts (in particular, Finance Minister A. Siluanov) and seriously criticized by others (A. Kudrin). Ambiguity and inconsistency in such matters seriously complicates the adoption of specific practice decisions. The process of «tune-up» risks seriously dragging out. In these circumstances, the specific proposals of experts on the solution of existing problems acquire special significance.

5. Competently set priorities in solving social problems

Characteristic manifestations of CSR in Western countries are the protection of minorities from discrimination and the observance of gender equality. Of course, these questions are extremely important and they need to be paid attention. However, in our opinion, these problems are problems of a "higher order". For Russia, at present, such issues as the quality of food products produced and imported, the evasion of employers from paying taxes (wages in envelopes), the inability of companies to provide jobs to the public (especially in single-industry towns), the low quality of free medicine, inability of the social environment for people with disabilities should be a priority for development of CSR in Russia.

\section{Recommendations for private sector:}

\section{Develop a strategic approach to CSR}

In a dynamically changing world, it is important to be aware of what needs to be done today, so that tomorrow not be defeated in the struggle for existence. Of course, strategic management cannot provide an accurate description of what will happen in the future. However, it allows on the basis of an analysis of various elements of the environment to assume how it will change, and to adapt to these changes in a timely manner.

A strategic approach to CSR is widely in demand in Western countries. In Russia, it is just beginning to form and is supported mainly by big business. From our point of view, it is the strategic approach that will allow domestic companies to develop successfully, keeping the course for the long term.

2. Adhere to the systemic and management approaches to $C S D$

Currently, most Russian companies focus on individual elements of the CSD, not considering it as a complex, multifactor process and an independent control facility $^{16}$. So, CSR is associated primarily with corporate

\footnotetext{
15 Рейтинг субъектов Российской Федерации по уровню развития сферы ГЧП за 2019 год. [Электронный источник]. - Режим доступа: https://www.economy.gov.ru/material/file/764aafac33fa544aec5b3008619e92a8/reiting_gchp_022020.pdf.

16 Кемберис С. Пять способов включить КСО в программу подготовки руководящих кадров / Социальная ответственность бизнеса, 2015. [Электронный источник]. - Режим доступа: https://soc-otvet.ru/pyat-sposobov-vklyuchit-kso-v-programmu-podgotovki-rukovodyashhih-kadrov/.
} 
charity, while the remaining elements of the «portfolio» of social investment are either absent or they are given much less attention. We are convinced that following the ISO 26000 standard will help domestic companies bring together in a single system the principles of social responsibility, approaches to its main topics and problems, as well as ways to integrate socially responsible behavior into managerial processes.

\section{Develop socially responsible investment}

Systemic unity in building the interaction of «business-stakeholders», improving this interaction, its subordination to the company's overall strategy in the field of CSR will improve the effectiveness of the CSD (Central Securities Depository) as a separate company, and the entire Russian business. Moreover, this approach will ensure a reduction in the risks of possible financial losses in the long term.

4. Create inter-corporate clusters (social clusters)

It should be noted that Russia already has experience in creating clusters in the fields of information technology, medicine, engineering, petrol chemistry, etc $^{17}$. This experience is highly likely to be useful in the creation of social clusters in terms of the general mechanism for cooperation of companies for joint decision of priority tasks.

5. Respond more actively to CSR initiatives proposed by the world community

Modern companies have the opportunity to contribute to sustainable development through SOI (Sustainability-oriented innovation). This is a type of investment, the goal of which is not so much to receive income on invested funds, but rather to create positive social changes, reduce the negative impact on the environment and comply with ethical standards [2]. Over the past 40 years of development of the world community, SDI from single practices has evolved to a separate segment of the stock market with its participants and infrastructure.

As this trend develops in Russia, companies can reconsider their conservative investment strategies, including social investments. The profitability of social businesses, according to experts, can reach 5-6\% per year, which corresponds to the average profitability of commercial funds with a conservative investment strategy [1].

\section{Recommendations for other actors}

Currently in the Russian society, there is a double attitude to the manifestation of social initiatives on the part of companies and their individual representatives. The most controversial area is corporate charity.
On the one hand, voluntary initiatives of business are perceived by the society with gratitude, which positively affects the business reputation of the companyphilanthropist.

On the other hand, there are many questions and suspicions about the «nobleness» of the donor. We must honestly admit that charity in our country is not always initiated by sincere intentions. Often it acts as a way to legalize funds obtained illegally, or in other words, «money laundering». Non-profit organizations (NGOs), in particular charitable foundations, are often at the center of scandals, which undermines the reputation of not only the company that poses as socially responsible, but also all charity in general. The society ceases to perceive socially responsible initiatives and begins to be suspicious of all such manifestations on the part of companies.

An important role in this matter is played by the mass media. Any incidents related to charity and ecology receive a wide response, while positive examples and manifestations of the best corporate practices often go unnoticed. In this situation, the media is advisable to conduct information campaigns in support of socially responsible companies. The companies themselves should cooperate with media representatives as one of the most important stakeholders. Tandem «business media» can be effective only if the companies themselves are ready to openly and convincingly declare their own decisions in the field of CSR.

It should be also highlighted that ethical consumption is a phenomenon characteristic of developed countries. With ethical consumption, information on the environmental and social properties of the product has a direct impact on the decision to purchase. The consumer consciously prefers the goods produced, processed and delivered with minimal damage to people, their producing, animals and the environment as a whole.

According to an international survey of 30,000 people conducted by Neilsen in 60 countries in 2014, on average $55 \%$ of consumers are willing to pay more for products and services provided by socially responsible companies ${ }^{18}$. And this share increases. In Russia, ethical consumption has not yet become widespread. However, this idea attracts more and more supporters from year to year.

Thus, recommendations were proposed on the formation of the Russian national CSR model. They are directed to state structures, the private sector, the media and society as a whole. It is assumed that following these recommendations, considering them as a single system of necessary measures, will contribute to the formation of the Russian national CSR model.

\footnotetext{
17 Карта кластеров России. [Электронный источник]. - Режим доступа:: http://map.cluster.hse.ru/.

18 Doing well by doing good. Increasingly, consumers care about corporate social responsibility, but does concern convert to consumption? Available at https://www.nielsen.com/wp-content/uploads/sites/3/2019/04/global-corporate-social-responsibility-report-june-2014.pdf.
} 


\section{Conclusion}

Speaking of the multitude of CSR national models that exist to date, it is worth asking the question: «Is it advisable for countries with still emerging national models to choose their own (unique) path of development in this direction?» In other words, is there a need to «start from scratch»?

Based on the results of the comparative analysis and taking into account the rich experience accumulated by «pioneer countries» for many decades, it can be concluded that one should consider this experience as a source of knowledge and best corporate practices.

Thus, the practical significance of the article lies in the fact that conclusions and proposed recommen- dations are aimed at contributing to the more effective development of CSR, as well as the formation of the national CSR model.

A study conducted by the authors revealed that more attention should be paid to increasing the value of CSR and creating favorable conditions for businesses to invest socially. Most effectively, these tasks can be solved taking into account three principles, such as ensuring CSR voluntariness, development of CSR within the framework of sustainable development [18] and taking into account regional features. Companies can also contribute to the development of the CSR institute by combining their projects into a comprehensive CSR practice.

\section{References}

1. Ilyina, G. N. (2014). [Social responsibility of Russian business: strategies and innovations]. Vestnik MGIMO-Universiteta [Bulletin of MGIMO-University]. Vol. 1 (34), pp. 216-224. (In Russ.).

2. Kholopov, V. A., Shkrebtienko, O. V. (2009). [Social partnership of power, business and society as a tool to improve the quality of life]. Izvestiya Tul'skogo gosudarstvennogo universiteta. Ekonomicheskiye i yuridicheskiye nauki [Proceedings of Tula State University. Economic and legal sciences]. Vol. 2-1, pp. 161-168. (In Russ.).

3. Annenkov, A. Y., Khmelev, I. B., Sokolnikova, I. V., Ilinam, O.N. (2019) Legal and economic aspects of developing corporate social responsibility in businesses. International Journal of Civil Engineering and Technology, 10 (2), 1892-1898. (In Engl.).

4. Cooper, E., Henderson, C., Kish, A. (2019) Corporate social responsibility and financial stability: evidence from the troubled asset relief program. Managerial Finance, 45 (8), 1111-1128. (In Engl.).

5. Da Silveira, L. M., Petrini M. (2018) Sustainable development and corporate social responsibility: a bibliometric analysis of international scientific production. Gestao e Producao, 25 (1), 56-67. (In Engl.).

6. Feng, Ch., Saginov, Yu. L.(2018) Corporate social responsibility as a business strategy. Human capital vocational education. Vol. 1 (25), pp, 81-87. (In Engl.).

7. González-Rodríguez, M. R., Martín-Samper, R. C., Köseoglu, M. A., Okumus, F. (2019) Hotels’ corporate social responsibility practices, organizational culture, firm reputation, and performance. Journal of Sustainable Tourism, 27 (3), pp. 398-419. (In Engl.).

8. Levchenko, O., Dogadaylo, Ya. (2018) Building a model of corporate social responsibility of the enterprise. Transport complex economy. Vol.31, pp. 80-90. (In Engl.).

9. Li, L., Li G., Yang, X., Yang, Z. (2019) Pursuing superior performance of service innovation through improved corporate social responsibility: from a knowledge acquisition perspective. Asia Pacific Journal of Marketing and Logistics. Vol. 31 (4), pp. 925-943. (In Engl.).

10. Melnik, M. V., Voronkova, O. Yu., Nikitochkina, Y. V., Tchuykova N. M., Davidyants A. A., Titova S. V. (2020) Corporate social responsibility of business as a factor of regional development. Entrepreneurship and Sustainability Issues. Vol. 7 (3), pp. 2170-2180. (In Engl.).

11. Myroshnychenko, I., Makarenko, I., Smolennikov, D., Buriak, A. (2019) The approach to managing corporate social and environmental responsibility in manufacturing. TEM Journal: Technology, Education, Management, Informatics, 8 (3), pp. 740-748. (In Engl.).

12. Ng, A. W., Tavitiyaman, P. (2020) Corporate social responsibility and sustainability initiatives of multinational hotel corporations. World Sustainability Series, pp. 3-15.

13. Rudakova, E.N., Pashentsev, D.A., Myrzalimov, R.M., Alpatov, Y.M., Baranov, V.A. (2019) Corporate social responsibility. Espacios. Vol.40 (22).

14. Sari, W. P., Ratnadi, Ni. M. D., Laxmi, L. E., Shankar, K., Wiflihani, W. (2020) Corporate social responsibility (CSR): concept of the responsibility of the corporations. Journal of Critical Reviews. Vol. 7 (1), pp. $241-245$. (In Engl.).

15. Serbănescu, C., Vintilescu, A. (2018) Efficiency and effectiveness in social assistance using corporate social responsibility and the economics of tagging. Romanian Journal of Political Science. Vol. 18 (2), pp. 91-115. (In Engl.).

16. Sulphey, M.M. (2017) Corporate social responsibility or corporate social irresponsibility: where should be the focus? Problems and Perspectives in Management. Vol. 15 (4), pp. 293-301.

17. Tiba, S., van Rijnsoever F. J., Hekkert, M. P. (2019) Firms with benefits: a systematic review of respon- 
sible entrepreneurship and corporate social responsibility literature. Corporate Social Responsibility and Environmental Management, 26 (2), 265-284.

18. Yevdokimova, M., Zamlynskyi, V., Minakova, S., Biriuk, O., Ilina, O. (2019) Evolution of corporate social responsibility applied to the concept of sustainable development. Journal of Security and Sustainability Issues, 8 (3), 473-480.

Information about the authors:

Denis Alexandrovich Pustokhin, PhD in Economics, Associate Professor of Logistics Department, State University of Management, Moscow, Russia

ORCID ID: 0000-0002-8138-8494, Researcher ID: AAN-4466-2020

e-mail: dpustokhin@yandex.ru

Irina Valeryevna Pustokhina, $\mathrm{PhD}$ in Economics, Associate Professor of Entrepreneurship and Logistics Department, Plekhanov Russian University of Economics, Moscow, Russia

ORCID ID: 0000-0001-5480-8871, Researcher ID: D-3508-2019

e-mail: pustohina.iv@rea.ru

The paper was submitted: 14.05.2020.

Accepted for publication: 19.08.2020.

The authors have read and approved the final manuscript.

Информация об авторах:

Денис Александрович Пустохин, кандидат экономических наук, доцент кафедры логистики, Государственный университет управления, Москва, Россия

ORCID ID: 0000-0002-8138-8494, Researcher ID: AAN-4466-2020

e-mail: dpustokhin@yandex.ru

Ирина Валерьевна Пустохина, кандидат экономических наук, доцент кафедры предпринимательства и логистики, Российский экономический университет имени Г.В. Плеханова, Москва, Россия

ORCID ID: 0000-0001-5480-8871, Researcher ID: D-3508-2019

e-mail: pustohina.iv@rea.ru

Статья поступила в редакцию: 14.05.2020; принята в печать: 19.08.2020.

Авторы прочитали и одобрили окончательный вариант рукописи. 